FisiPublik : Jurnal IImu Sosial dan Politik

https://journal.uwgm.ac.id/index.php/fisipublik

P-ISSN: 2528-2689; E-ISSN: 2540-9751

Vol 04 No 02 November 2019,

\title{
Collaborative Governance dalam Mengembangkan Wisata Edukasi di Desa Kamiri Kecamatan Masamba Kabupaten Luwu Utara
}

\author{
Dwi Alamsyah', Nuryanti Mustari', Rudi Hardi ${ }^{3}$, Ansyari Mone ${ }^{4}$ \\ Program Studi Ilmu Pemerintahan, Fakultas Ilmu Sosial dan Ilmu Politik, \\ Universitas Muhammadiyah Makassar \\ E-mail : alamsyahdwi07@gmail.com,nuryantimustari@unismuh.ac.id, \\ rudihardi@unismuh.ac.id,ansyari@unismuh.ac.id
}

\begin{abstract}
Abstrak
Penelitian ini bertujuan untuk mengetahui Collaborative Governance dalam Mengembangkan Wisata Edukasi di Desa Kamiri, Kecamatan Masamba, Kabupaten Luwu Utara. Rumusan masalah dalam penelitian ini adalah "Bagaimana Collaborative Governance dalam Mengembangkan Wisata Edukasi di Desa Kamiri, Kecamatan Masamba, Kabupaten Luwu Utara?" Tipe penelitian menggunakan analisis deskriptif dengan pendekatan kualitatif. Fokus penelitian berdasar pada teori ANSELL dan GASH tentang tahapan-tahapan dalam proses collaborative governance yaitu face to face, trust building, commitment to process, dan shared understanding. Adapun teknik pengumpulan data meliputi wawancara, observasi dan dokumentasi. Hasil penelitian menunjukkan bahwa dalam proses kolaborasi yang diakukan sudah cukup baik dalam mengembangkan wisata edukasi di Desa Kamiri, Kecamatan Masamba, Kabupaten Luwu Utara. Tahapan-tahapan dalam proses collaborative governance (1) face to face dalam mengembangkan wisata edukasi telah melibatkan pemerintah, masyarakat dan pengelola dengan melakukan pertemuan secara langsung dalam bentuk forum musyawarah. (2) Trust building atau membangun kepercayaan dengan adanya sebuah pelatihan pengembangan SDM dan menyediakan tempat sampah dilokasi wisata. (3) Commitment to process atau komitmen terhadap proses kolaborasi dalam mengambangkan wisata edukasi telah melibatkan masyarakat dan pemerintah dalam proses pengembangannya (4) share Understanding untuk menilai sejauh mana proses kolaborasi yang dihasilkan dalam mengembangkan wisata edukasi yaitu terdapat forum pembinaan untuk pengelola, penyediaan kontrol atau pamong wisata untuk membantu dalam pengamanan wisata edukasi dan pengadaan promosi objek wisata.
\end{abstract}

Kata kunci : Collaborative Governance, Wisata, Edukasi, 
FisiPublik : Jurnal IImu Sosial dan Politik

https://journal.uwgm.ac.id/index.php/fisipublik

P-ISSN: 2528-2689; E-ISSN: 2540-9751

Vol 04 No 02 November 2019,

Collaborative governance in developing education tourism in Village Kamiri, Masama District North Luwu Regency

\begin{abstract}
This study aims to determine Collaborative Governance in Developing Educational Tourism in Kamiri Village, Masamba District, North Luwu Regency. The formulation of the problem in this study is "How is Collaborative Governance in Developing Educational Tourism in Kamiri Village, Masamba District, North Luwu Regency?" This type of research uses descriptive analysis with a qualitative approach. The focus of the research is based on ANSELL and GASH theories about the stages in the collaborative governance process, namely face to face, trust building, commitment to process, and shared understanding. The data collection techniques include interviews, observation and documentation. The results of the study showed that in the collaborative process which had been carried out quite well in developing educational tourism in Kamiri Village, Masamba District, North Luwu Regency. The stages in the collaborative governance process (1) face to face in developing educational tourism have involved the government, community and managers by holding meetings directly in the form of a deliberative forum. (2) Trust building or building trust with a training in human resource development and providing trash bins in tourist sites. (3) Commitment to process or commitment to the collaborative process in developing educational tourism has involved the community and government in the development process (4) shared understanding to assess the extent of the collaborative process produced in developing educational tourism, namely there is a guidance forum for managers, provision of control or tourist guardian to assist in securing education tourism and procuring tourist attractions.
\end{abstract}

Keywords: Collaborative Governance, Educational, Tourism 
FisiPublik : Jurnal IImu Sosial dan Politik

https://journal.uwgm.ac.id/index.php/fisipublik

P-ISSN: 2528-2689; E-ISSN: 2540-9751

Vol 04 No 02 November 2019,

\section{Pendahuluan}

Pariwisata merupakan salah satu hal yang penting bagi suatu negara. Dengan adanya pariwisata, suatu negara atau lebih khusus lagi Pemerintah Daerah tempat obyek wisata itu berada mendapat pemasukan dari pendapatan setiap obyek wisata. Pariwisata merupakan potensi wisata yang dimiliki setiap daerah, baik yang berupa wisata alam, wisata budaya maupun wisata buatan, dan lain-lain. Hal ini mengindikasikan bahwa setiap daerah mempunyai berbagai potensi wisata yang dapat digali, diolah, dikelola serta dikembangkan untuk memenuhi kebutuhan masyarakatnya terhadap sarana hiburan atau sarana rekreasi.

Sektor pariwisata di Indonesia adalah salah satu sektor yang memegang peranan penting dalam keberlangsungan perekonomian Indonesia. Jika mendapatkan pengelolaan yang baik dan benar, pembangunan pariwisata sebagai salah satu industri akan menciptakan kemakmuran melalui perkembangan transportasi, akomodasi, dan komunikasi yang menciptakan peluang kerja yang relatif besar (Hadji, 2017). Pembangunan dalam pariwisata merupakan salah satu sektor yang potensial yang perlu dikembangkan, hal ini sesuai pernyataan $\mathrm{T}$. Christie and D. Elizabeth Cromptondalam (Kurniawan, 2013) bahwa Pariwisata bisa menjadi alat pengembangan yang potensial, menghasilkan pertumbuhan ekonomi, diversifikasi ekonomi, membantu mengurangi kemiskinan dan juga menciptakan hubungan timbal balik dengan produksi lainnya dan sektor penyedia jasa.

Pariwisata dapat menumbuhkan dan meningkatkan pengenalan budaya dan rasa cinta terhadap tanah air. Dari sektor pariwisata juga dapat memberikan sumbangan terhadap penerimaan Pendapatan Asli Daerah bersumber dari pajak, retribusi parkir dan karcis atau dapat mendatangkan devisa dari para wisatawan yang berkunjung. Adanya pariwisata juga akan menumbuhkan usaha-usaha ekonomi disekitar area wisata dan menunjang kegiatannya sehingga dapat meningkatkan pendapatan masyarakat.

Berdasarkan Peraturan Pemerintah Republik Indonesia No 50 Tahun 2011 tentang Rencana Induk Pembangunan Kepariwisataan Nasional Tahun 2010-2025 bahwa kelembagaan kepariwisataan adalah kesatuan unsur beserta jaringannya 
FisiPublik : Jurnal IImu Sosial dan Politik

https://journal.uwgm.ac.id/index.php/fisipublik

P-ISSN: 2528-2689; E-ISSN: 2540-9751

Vol 04 No 02 November 2019,

yang dikembangkan secara terorganisasi, meliputi pemerintah, pemerintah daerah, swasta dan masyarakat, sumber daya manusia, regulasi, dan mekanisme operasional, yang secara berkesinambungan guna menghasilkan perubahan ke arah pencapaian tujuan dibidang kepariwisataan. Oleh sebab itu, diperlukan adanya sebuah kerjasama atau dikenal dengan collaborative governanceantara pemerintah daerah yang terkait terkhususnya dinas kebudayaan dan pariwisata didaerah tersebut dengan masyarakat setempat agar dapat memperbanyak variasi produk baru berbasis sumber daya alam, dengan prinsip pelestarian lingkungan dan partisipasi masyarakat, hal ini merupakan strategi yang ditempuh untuk meningkatkan pemanfaatan keunikan daerah dan persaingan di tingkat regional dengan daerah lain.

Kabupaten Luwu Utara adalah salah satu daerah di Indonesia yang terletak di pulau Sulawesi yang memiliki potensi pariwisata cukup banyak yang bisa dimanfaatkan. Kabupaten Luwu Utara merupakan daerah yang memiliki keragaman budaya dan tradisi yang selalu menarik untuk diperhatikan. Tidak hanya itu, Kabupaten yang terletak di ujung utara Provinsi Sulawesi Selatan itu, berjarak $450 \mathrm{~km}$ dari Kota Makassar, juga memiliki sejumlah lokasi wisata budaya dan wisata alam yang potensial untuk dikembangkan seperti, Air Terjun Sarambualla, Pincara, Pantai Lemo, Buntu Tabuan, dan lain sebagainya.

Potensi wisata tersebut patut untuk dikembangkan oleh pemerintah daerah dalam hal ini Dinas Kebudayaan dan Pariwisata sebagai leading sector dengan menata sektor-sektor pariwisata yang dimiliki. Namun kenyataannya beberapa potensi-potensi wisata yang ada belum dimanfaatkan secara maksimal oleh pemerintah daerah dalam hal ini Dinas Kebudayaan dan Pariwisata. Banyak dari potensi wisata tersebut terbengkalai dan tidak dikelola dengan baik, seperti objek wisata alam Buntu Tabuan yang saat ini akses jalan menuju keobjek wisata tersebut belum memadai, sarana dan prasarana penunjang objek wisata seperti objek wisata alam lainnya.

Kondisi lingkungan, sarana dan prasarana objek-objek wisata di Kabupaten Luwu Utara masih kurang memadai, serta daya tarik objek wisata masih relative belum banyak dikunjungi wisatawan domestik maupun 
FisiPublik : Jurnal IImu Sosial dan Politik

https://journal.uwgm.ac.id/index.php/fisipublik

P-ISSN: 2528-2689; E-ISSN: 2540-9751

Vol 04 No 02 November 2019,

mancanegara, diperlukan adanya perhatian yang mendalam dari Pemerintah Daerah khususnya Dinas Kebudayaan dan Pariwisata, agar upaya pengembangan sektor pariwisata yang dilakukan bisa memberikan hasil yang optimal dan menguntungkan bagi masyarakat lokal.

Situasi dan kondisi daerah yang berbeda baik dari potensi wisata alam, ekonomi, adat budaya, mata pencaharian, kependudukan dan lain sebagainya yang menuntut pola pengembangan yang berbeda pula, baik dari segi cara atau metode, prioritas, maupun penyiapannya. Proses penentuan pola pengembangan ini membutuhkan peran aktif dari semua pihak, agar sifatnya integratif, komprehensif dan sinergis. Banyaknya daerah tujuan wisata yang sangat potensial di Indonesia apabila dilihat dari sisi daya tarik alam dan budaya yang dimilikinya. Namun belum bisa dijual atau mampu bersaing dengan daerah tujuan wisata baik di kawasan regional maupun internasional. Daya tarik yang tersedia belum dikemas secara profesional, rendahnya mutu pelayanan yang diberikan, interpretasi budaya atau alam yang belum memadai, atau karena belum dibangunnya citra yang membuat wisatawan tertarik untuk datang mengunjungi dan lain sebagainya.Daerah harus melakukan inovasi, kreasi dan pengembangan terhadap potensi pariwisata dengan mencari dan menciptakan peluang baru terhadap produk pariwisata yang diunggulkan.

Angka statistik perkembangan kenaikan kunjungan wisatawan dari tahun ke tahun menggambarkan peluang yang sangat potensial bagi pengembangan usaha destinasi wisata. Akan tetapi, otonomi daerah memberikan kewenangan kepada masing-masing kabupaten/kota menimbulkan persaingan bauran produk yang tidak terspesialisasi. Sehingga produk-produk yang ada saat ini cenderung monoton, daya tarik wisata yang ditawarkan cenderung itu-itu saja, akibatnya banyak destinasi wisata yang kurang laku di pasar wisata. Sebagaimana fenomena di lapangan, beberapa pengelola destinasi wisata di Kabupaten Luwu Utara tepatnya di desa Kamiri mulai menyadari adanya kejenuhan produk-produk wisata seperti diatas. Oleh karena itu, beberapa pengelola mulai berinisiatif untuk menyajikan konsep wisata yang berbeda dari sebelumnya. Salah satu konsep kegiatan wisata yang masih baru adalah destinasi wisata alam bertema edukasi 
FisiPublik : Jurnal IImu Sosial dan Politik

https://journal.uwgm.ac.id/index.php/fisipublik

P-ISSN: 2528-2689; E-ISSN: 2540-9751

Vol 04 No 02 November 2019,

seperti yang dirintis oleh pengelola destinasi wisata rumah pohon, River Tubing, dan beberapa objek wisata lainnya.

Destinasi wisata rumah pohon yang terdapat di Desa Kamiri sejak dibuka pada Februari 2016 tersebut menyuguhkan objek wisata yang bernuansa edukasi dimana selain berwisata, wisatawan juga bisa belajar diantaranya terdapat kelas bahasa inggris, daur ulang sampah dan berbagai kesenian daerah setempat. Dengan adanya wisata edukasi ini dijadikan sebagai salah satu objek wisata yang dapat menarik perhatian bagi para wisatawan agar datang untuk berkunjung dan menikmati liburan sambil belajar. Kemudian untuk meningkatkan dan mengembangkan wisata edukasi diDesa Kamiri, Kecamatan Masamba, Kabupaten Luwu Utaradiperlukan adanya kerjasama antara pemerintah daerah khususnya dinas kebudayaan dan pariwisata dengan masyarakat setempat khususnya komunitas rumah pohon.

Berdasarkan uraian diatas, peneliti akan melakukan penelitian dengan judul "Collaborative Governance dalam Mengembangkan Wisata Edukasi di Desa Kamiri, Kecamatan Masamba, Kabupaten Luwu Utara”. Rumusan masalah dalam kajian ini adalah "Bagaimana Collaborative Governance dalam Mengembangkan Wisata Edukasi di Desa Kamiri, Kecamatan Masamba, Kabupaten Luwu Utara?"

Tujuan penelitian ini adalah untuk mengetahui Collaborative Governance dalam Mengembangkan Wisata Edukasi di Desa Kamiri, Kecamatan Masamba, Kabupaten Luwu Utara. Menurut Charalabidiset Collaborative Governance muncul di era paradigma governance, dimana pada saat itu masyarakat semakin berkembang sehingga pemerintah menghadapi masalah yang lebih kompleks. Disisi lain, pemerintah juga memiliki keterbatasan waktu untuk mengatasi masalah tersebut sehingga membutuhkan kolaborasi dengan aktor-aktor eksternal (Arrozaaq,2016)

Collaborative governance merupakan suatu forum yang digunakan untuk mencapai suatu tujuan. Collaborative Governance merupakan kondisi yang mana pemerintah untuk memenuhi tujuan publik melalui kolaborasi antar organisasi maupun individu. Hal senada juga diungkapkan oleh Holzer dalam (Arrozaaq, 
FisiPublik : Jurnal IImu Sosial dan Politik

https://journal.uwgm.ac.id/index.php/fisipublik

P-ISSN: 2528-2689; E-ISSN: 2540-9751

Vol 04 No 02 November 2019,

2016) yang menyatakan bahwa Collaborative Governance adalah kondisi ketika pemerintah dan swasta berupaya mencapai suatu tujuan bersama untuk masyarakat. Collaborative Governance juga dapat mengambarkan keadaan saling ketergantungan antar aktor. Keinginan melakukan Collaborative Governance muncul karena para aktor menyadari adanya keterbatasan yang mereka miliki. Kemudian, aktor tersebut perlu menyatakan keinginan dan kesedian mereka untuk menjalin hubungan yang lebih erat dengan aktor lain. Collaborative Governance merupakan usaha serta respon yang dilakukan pemerintah dalam menyelesaikan masalah publik yang terjadi.Dimana dalam penyelesaian masalah publik ini pemerintah harus melalukakan kerjasama dengan aktor non pemerintah seperti pihak swasta, masyarakat dan lain-lain (Sudarmo dan Mutiarawati, 2017).

Menurut Ansell dan gash Collaborative Governance adalah pemerintahan yang disusun dengan melibatkan badan publik dan organisasi non pemerintah dalam proses pengambilan keputusan secara formal, berorientasi musyawarah mufakat, dan ada pembagian peran untuk melaksanakan kebijakan publik atau mengelola program publik, serta asset publik. Kolaborasi dalam penyelenggaraan pemerintahan merupakan suatu hal yang dibutuhkan dalam praktik pemerintahan sekarang ini. (Sambodo, 2016) Ada berbagai alasan yang melatar belakangi adanya kolaborasi tiap lembaga atau institusi. Collaborative governance tidak muncul secara tiba-tiba karena hal tersebut ada disebabkan oleh inisiatif dari berbagai pihak yang mendorong untuk dilakukannya kerjasama dan koordinasi dalam menyelesaikan masalah yang sedang dihadapi oleh publik (Junaidi. 2015). Collaborative Governance atau kolaborasi penyelenggaraan pemerintahan muncul sebagai respon atas kegagalan implementasi dan tingginya biaya dan adanya politisasi terhadap regulasi (Ansell dan Gash, 2008).

Berdasarkan pendapat berbagai ahli dapat disimpulkan bahwa Collaborative Governance merupakan salah satu cara untuk merespon keinginan para pemangku kepentingan terlibat dalam pelaksanaan pembangunan dan merespon keterbatasan pendanaan pemerintah yang tidak bisa mengikuti perkembangan tuntutan masyarakat akan kinerja pemerintah yang semakin baik dengan tujuan mendapatkan sumberdaya guna melaksanakan pembangunan sesuai 
FisiPublik : Jurnal IImu Sosial dan Politik

https://journal.uwgm.ac.id/index.php/fisipublik

P-ISSN: 2528-2689; E-ISSN: 2540-9751

Vol 04 No 02 November 2019,

harapan para pemangku kepentingan tersebut. Collaborative Governance merupakan proses dari struktur jejaring multi-organisasi lintas sektoral (Government, Private Sector, Civil Society) yang membuat kesepakatan bersama, keputusan bersama, pencapaian konsensus melalui interaksi formal maupun informalpembuatan dan pengembangan norma-norma dalam interaksi yang bersifat saling menguntungkan dalam mencapai tujuan bersama. Oleh karena itu, di dalam kolaborasi interaksi yang muncul bersifat egaliter yaitu seluruh aktor mempunyai kedudukan yang sama.Dalam proses Collaborative Governance diperlukan reformasi dengan mensinergikan berbagai perspektif pemangku kepentingan, lebih dekat dengan masyarakat, dan memperluas kerjasama dengan pihak lain untuk memenuhi kebutuhan sumber daya, dan perekrutan SDM.

Pilihan untuk mendorong berkembangnya kepariwisataan dapat timbul karena diyakini akan adanya kemanfaatan dari berkembangnya pariwisata. Secara teoritis maka dapat dilihat bahwa manfaat dan dampak pembangunan pariwisata yang ditinjau setidaknya dari empat sudut pandang yang meliputi manfaat ekonomi, manfaat sosial budaya, manfaat dalam berbangsa dan bernegara, serta manfaat bagi lingkungan dalam (Sedarmayanti, 2015).

Mengapa dikembangkan pariwisata pada suatu daerah baik secara lokal, regional maupun internasional. Pertama, yang disebutnya sebagai alasan utama sangat erat kaitannya dengan pembangunan perekonomian daerah atau negara tersebut. Alasan kedua menurutnya ialah, pengembangan pariwisata lebih banyak bersifat non ekonomis, seperti memelihara adat istiadat, bangunan-bangunan kuno, kesenian daerah serta membuat suasana yang nyaman, bersih dan aman. Terakhir atau yang ketiga, adalah untuk menghilangkan kepicikan berfikir, dan mengurangi salah pengertian (Yoeti, 2008) Menurut Vorlaufer ada tiga alasan utama Kebijakan pembangunan pariwisata dilakukan oleh pemerintah maupun pemerintah daerah antara lain; pertama, karena adanya keyakinan bahwa pembangunan pariwisata mampu meningkatkan devisa, kesempatan kerja; kedua, meredistribusi pendapatan, menyeimbangkan pembangunan inter-regional; ketiga, menciptakan diversifikasi aktivitas ekonomi dan kelembagaan baru (Murdiastuti, 2014) . 
FisiPublik : Jurnal IImu Sosial dan Politik

https://journal.uwgm.ac.id/index.php/fisipublik

P-ISSN: 2528-2689; E-ISSN: 2540-9751

Vol 04 No 02 November 2019,

Berdasarkan berbagai kajian yang dilakukan para ahli dapat disimpulkan bahwa sumbangan pariwisata yang secara signifikan pada perkembangan ekonomi suatu negara atau daerah tampak dalam tiga bentuk utama yaitu: perluasan kesempatan kerja, peningkatan pendapatan (devisa), dan pemerataan pembangunan antar wilayah. Besaran dampak tersebut bergantung kepada tingkat perkembangan pariwisata.

Melaksanakan berbagai kebijakan di bidang kepariwisataan tersebut khususnya menyangkut pariwisata di tingkat daerah dilakukan dengan pemahaman bahwa berdasarkan Peraturan Pemerintah (Nomor 12 tahun 2008), pemerintah daerah juga mempunyai bagian urusan yang harus dilaksanakan, baik oleh pemerintah daerah provinsi, kabupaten dan kota. Dengan dasar ini maka pemerintah harus megambil langkah-langkah dalam mengembangkan wisata yang ada di Kabupaten Luwu Utara terutama wisata edukasi yang ada di Desa Kamiri, Kecamatan Masamba. Secara Etimologis, edukasi berasal dari kata latin yaitu educare artinya "memunculkan". "membawa", "melahirkan". Dalam pengertian secara luas edukasi adalah setiap tindakan atau pengetahuan, pengalaman yang memiliki efek formatik pada karakter, kemampuan pikiran atau kemampuan fisik dalam individu. Jadi beberapa pengertian diatas wisata edukasi adalah konsep wisata yang menerapkan pendidikan nonformal tentang suatu pengetahuan kepada wisatawan yang berkunjung kesuatu obyek wisata.

Menurut Undang-Undang No 23 tahun 2014 yang dimaksud dengan pemerintahan daerah adalah penyelenggaraan urusan pemerintahan oleh pemerintah daerah dan dewan perwakilan rakyat daerah menurut asas otonomi dan tugas pembantuan dengan prinsip otonomi seluas-luasnya dalam sistem dan prinsip Negara Kesatuan Republik Indonesia sebagaimana dimaksud dalam Undang-Undang Dasar Negara Republik Indonesia tahun 1945.

Berdasarkan Peraturan Pemerintah Republik Indonesia No 18 Tahun 2016 tentang Perangkat Daerah disebutkan bahwa "Dinas Daerah Kabupaten/Kota merupakan unsur pelaksana urusan pemerintahan yang menjadi kewenangan daerah dipimpin oleh kepala dinas daerah kabupaten/kota yang berkedudukan dibawah dan bertanggung jawab kepada bupati/wali kota melalui sekretaris daerah 
FisiPublik : Jurnal Ilmu Sosial dan Politik

https://journal.uwgm.ac.id/index.php/fisipublik

P-ISSN: 2528-2689; E-ISSN: 2540-9751

Vol 04 No 02 November 2019,

kabupaten/kota”. Pengunjung wisata edukasi paling banyak pada tahun 2017 yaitu sebanyak 3600 orang, jumlah pengunjung lebih banyak apabila hari libur bersama yaitu pada saat hari raya idul fitri maupun idul adha karena banyak yang menikmati liburan dengan keluarga. Sedangkan untuk hari-hari biasa pengunjung lebih banyak pada saat weekend atau hari minggu dibandingkan hari lainnya. Pada tahun 2016 masih kurang pengunjung karena pada tahun ini baru dimulai pembangunan rumah pohon yang awalnya hanya berlantai satu hingga enam bulan kemudian menjadi tiga lantai. Oleh karena itu, pada tahun ini belum banyak yang mengetahui objek wisata ini. Pada tahun 2018 pengunjung mulai berkurang karena kelas bahasa inggris, painting dan daur ulang sampah sudah jarang dilakukan sehingga para pengunjung mulai merasa bosan.

\section{Metodologi}

Jenis penelitian ini adalah penelitian kualitatif untuk menjawab fenomena tentang apa yang dialami oleh masyarakat. Jenis peneltian yang berusaha menggambarkan obyek atau subyek yang diteliti sesuai dengan apa adanya dengan tujuan menggambarkansecara sistematis fakta dan karakteristik obyek yang diteliti secara tepat. Tipe penlitian adalah analisis deskriptif yang digunakan untuk menggambarkan atau mendeskripsikan data tanpa bermaksud membuat kesimpulan tapi hanya menjelaskan kelompok data itu saja.

Penelitian ini dilaksanakan di Desa Kamiri, Kecamatan Masamba, Kabupaten Luwu Utara dan adapun waktu yang digunakan dalam penelitian ini adalah 2 bulan, agar hasil dari penelitian sesuai dengan tujuan yang ingin dicapai oleh peneliti. Pemilihan obyek lokasi penelitian tersebut karena di Desa Kamiri Kecamatan Masamba merupakan satu-satunya obyek wisata yang mengembangkan wisata edukasi di Kabupaten Luwu Utara.

Informan adalah orang-orang yang betul paham atau pelaku yang terlibat langsung dengan permasalahan penelitian. Informan yang dipilih adalah yang dianggap relevan dalam memberikan informasi. Adapun yang menjadi informan dalam penelitian ini adalah Kepala Dinas Kebudayaan dan Pariwisata Luwu Utara, Kepala UPT Pengembangan Objek Wisata, Sekretaris Desa Kamiri, 
FisiPublik : Jurnal IImu Sosial dan Politik

https://journal.uwgm.ac.id/index.php/fisipublik

P-ISSN: 2528-2689; E-ISSN: 2540-9751

Vol 04 No 02 November 2019,

Pengelola Rumah Pohon, Masyarakat Sekitar dan Pengunjung Objek Wisata Edukasi.

Teknik Pengumpulan data menggunakan Obesrvasi, yaitu pengumpulan data melalui pengamatan langsung dengan mengamati kondisi objek wisata edukasi dan mengamati peran serta pemerintah, masyarakat dan pengelola dalam berkolaborasi mengembangkan wisata edukasi, wawancara yaitu mengumpulkan data secara langsung dengan cara mengajukan pertanyaan langsung kepada informan, dan dokumentasi yaitu yaitu metode pengambilan data berdasarkan dokumen-dokumen, foto-foto dan arsip yang relevan sebagi sumber data.

Uji Triangulasi digunakan sebagi uji keabsahan data dalam penelitian ini, untuk keperluan triangulasi maka dilakukan tiga cara yaitu Triangulasi Sumber yaitu Pengumpulan data yang dilakukan dengan cara mengecek pada sumber lain keabsahan data yang telah diperoleh sebelumnya, triangulasi teknik yaitu Pengumpulan data yang diperoleh dari satu sumber dengan menggunakan bermacam-macam cara atau teknik tertentu untuk diuji keakuratan dan ketidakakuratannya, Dan triagulasi waktu yaitu berkenan dengan waktu pengambilan data yang berbeda agar data yang diperoleh lebih akurat dan kredibel dari setiap hasil wawancara yang telah dilakukan pada informan.

Teknik analisis data menurut Miles dan Hubermen penelitian kualitatif terdapat tiga alur kegiatan yang terjadi secara bersamaan. Aktiivitas dalam analisis data yaitu Kondensasi data (Condentation) merujuk pada proses memilih, menyederhanakan, mengabstrakkan, dan atau mentransformasikan data yang mendekati keseluruhan bagian dari catatan-catatan lapangan secara tertulis, transkip wawancara, dokumen-dokumen dan materi-materi empiris lainnya, penyajian data (display) adalah sebuah pengorganisasian, penyatuan dari informasi yang memungkinkan penyimpulan dan aksi. Penyajian data dilakukan dengan singkat, bagan, hubungan dantar kategori, dan sejenisnya, penarikan kesimpulan (verification) adalah menarik kesimpulan dan verifikasi, dimana kesimpulan awal yang dikemukakan masih bersifat sementara dan akan berubah bila ditemukaan bukti-bukti yang valid dan konsisten (Misna, 2015)

\section{Pembahasan}


FisiPublik : Jurnal IImu Sosial dan Politik

https://journal.uwgm.ac.id/index.php/fisipublik

P-ISSN: 2528-2689; E-ISSN: 2540-9751

Vol 04 No 02 November 2019,

Proses kolaborasi menurut Ansell and Gash (2008) yaitu :

1. Face to face

Collaborative governance didasarkan pada face to face antara pemangku kepentingan sebagai proses konsensus dan fokus pada kerahmahtamaan. Dialog secara langsung diperlukan pemangku kepentingan untuk mengidentifikasi peluang keuntungan bersama. Face to face adalah sarana yang memberikan suatu kepercayaan dalam menyatukan program yang ditetapkan secara bersama. Dari beberapa hasil wawancara terkait dengan face to face atau dialog secara langsung tentang kolaborasi antara pemerintah dengan komunitas rumah pohon dalam mengembangkan wisata edukasi didesa Kamiri, Kabupaten Luwu Utara dari beberapa informan dapat disimpulkan bahwa, komunikasi antara pemerintah dengan komunitas rumah pohon sudah berjalan dengan baik karena sudah melibatkan pemerintah, masyarakat sekitar objek wisata dan pengelola dengan melakukan pertemuan secara langsung dalam bentuk forum musywarah sehingga terjadi kerjasama atau kolaborasi yang baik dalam pengembangan wisata edukasi ini sehingga tujuan dari dialog untuk menyatukan sebuah pendapat dari berbagai pihak dapat diwujudkan.

\section{Trust building}

Proses kolaboratif tidak hanya tentang negoisasi tetapi tentang membangun kepercayaan. Membangun kepercayaan merupakan fase terpisah dari dialog dan negoisasi hal yang substantif. Berdasarkan wawancara mengenai trust building atau membangun kepercayaan yang dilakukan dalam proses kolaborasi pengembangan wisata edukasi antara dinas kebudayaan dan pariwisata dan komunitas rumah pohon yang dapat disimpulkan dari hasil wawancara beberapa informan bahwa, suatu kepercayaan telah terbangun dengan sangat baik antara pemerintah, masyarakat dan juga pengelola terutama dari masyarakat karena pada awal mula perencanaan pembangunan objek rumah pohon ini masyarakat belum sepenuhnya memberikan ijin terkait dengan pembagian lahan yang akan menjadi tempat pembangunannya akan tetapi dengan adanya sebuah musyawarah secara langsung dan juga penjelasan mengenai berbagai manfaat yang akan didapatkan maka masyarakat 
FisiPublik : Jurnal IImu Sosial dan Politik

https://journal.uwgm.ac.id/index.php/fisipublik

P-ISSN: 2528-2689; E-ISSN: 2540-9751

Vol 04 No 02 November 2019,

memberikan kepercayaan penuh untuk pembangunan wisata tersebut kepada pengelola. Kemudian dari pemerintah telah memberikan kepercayaan untuk pengelola dengan mengadakan pelatihan pengembangan SDM dan menyediakan beberapa tempat sampah dilokasi wisata.

3. Commitment to process

Komitmen terkait motivasi berpartisipasi dalam collaborative governance. Pemangku kepentingan ingin berpartisipasi untuk mengamankan legitimasi dalam memenuhi kewajiban hukum. Komitmen terhadap proses berarti mengembangkan keyakinan tawar menawar itikad baik untuk saling menguntungkan cara terbaik mencapai kebijakan yang diinginkan dan membutuhkan kesediaan untuk melaksanakan musyawarah. Dalam hal ini terdapat sarana yang digunakan untuk menyampaikan kontrol guna mengawasi jalannya kegiatan wisata edukasi ini. Dari beberapa jawaban yang terdiri dari berbagai pertanyaan untuk menggali informasi dari informan terkait komitmen terhadap proses kolaborasi antara dinas kebudayaan dan pariwisata dan komunitas rumah pohon dalam mengembangkan wisata edukasi di Desa Kamiri, Kecamatan Masamba, Kabupaten Luwu Utara dapat disimpulkan bahwa, terkait dengan komitmen belum dilaksanakan secara maksimal karena dalam hal ini masih banyak kekurangan seperti kelengkapan sarana dan prasaranan dan SDM. Akan tetapi dalam proses pengembangannya telah melibatkan masyarakat untuk mewujudkan,keamanan, kebersihan dan ketertiban. Kemudian pemerintah telah melakukan sosialisasi, membina, dan juga melakukan promosi objek wisata edukasi ini.

\section{Share understanding}

Pemahaman atas keputusan bersama menyiratkan persetujuan definisi masalah berarti persetujuan tentang pengetahuan yang relevan diperlukan untuk mengatasi masalah. Pengembangan pemahaman atas keputusan bersama dapat dilaksanakan dalam proses kolaboratif dan berguna untuk menilai sejauh mana pembelajaran kolektif yang dihasilkan dari kolaborasi. Oleh karena perlu adanya suatu interaksi yang dilakukan antara pemerintah dan masyarakat agar dapat diketahui sejauh mana proses kolaborasi yang terjadi. Dari beberapa 
FisiPublik : Jurnal IImu Sosial dan Politik

https://journal.uwgm.ac.id/index.php/fisipublik

P-ISSN: 2528-2689; E-ISSN: 2540-9751

Vol 04 No 02 November 2019,

jawaban terkait dari hasil wawancara dengan beberapa informan terkait share understanding atau untuk menilai sejauh mana proses dari kolaborasi yang dihasilkan antara dinas kebudayaan dan pariwisata dengan komunitas rumah pohon dalam mengembangkan wisata edukasi di Desa Kamiri, Kecamatan Masamba, Kabupaten Luwu Utara dapat disimpulkan bahwa, dalam proses pengembangan wisata edukasi ini sudah berjalan dengan baik karena pemerintah telah berupaya semaksimal mungkin seperti mengadakan sosialisasi pelatihan SDM, penyediaan tong sampah dan juga PAMONG WISATA untuk keamanan lokasi wisata. Meskipun masih ada kekurangan akan tetapi kekurangan tidak menjadi hambatan untuk pengembangannya karena selama proses kolaborasi ini terdapat forum sosialisasi maupun pembinaan yang diselenggaran oleh pemerintah dan promosi yang dilakukan juga sudah sangat baik hal ini dapat dilihat dari jumlah pengunjung yang selalu bertambah yang menandakan bahwa wisata edukasi ini sudah dikenal dimanamana.

\section{Kesimpulan}

Berdasarkan uraian pada bab sebelumnya bahwa peneliti berfokus pada tahapan-tahapan dalam proses collaborative governance dalam mengembangkan wisata edukasi di Desa Kamiri, Kecamatan Masamba, Kabupaten Luwu Utara. Berikut beberapa kesimpulan yang dapat ditarik dari bab pembahasan sebagai berikut:

1. Face to face dalam proses collaborative governance melibatkan pemerintah, masyarakat sekitar objek wisata dan pengelola dengan melakukan pertemuan secara langsung dalam bentuk forum musyawarah untuk membahas perencanaan pengembangan wisata edukasi.

2. Trust building atau membangun kepercayaan yang dilakukan dengan adanya sebuah pelatihan pengembangan SDM dan juga dalam kebersihan menyediakan beberapa tempat sampah di lokasi wisata.

3. Commitment to process atau komitmen terhadap proses kolaborasi telah melibatkan masyarakat untuk menjaga keamanan, kebersihan dan ketertiban. 
FisiPublik : Jurnal IImu Sosial dan Politik

https://journal.uwgm.ac.id/index.php/fisipublik

P-ISSN: 2528-2689; E-ISSN: 2540-9751

Vol 04 No 02 November 2019,

Kemudian melibatkan pemerintah dalam melakukan sosialisasi, melakukan kunjungan, memantau, membina dan melakukan promosi.

4. Shared understanding untuk menilai sejauh mana proses dari kolaborasi yang dihasilkan yaitu terdapat forum sosialisasi maupun pembinaan yang diselenggarakan oleh pemerintah, menyediakan pamong wisata untuk mengontrol keamanan wisata.

\section{Daftar Pustaka}

Arrozaaq, D.L.C. 2016. Collaborative Governance (Studi tentang Kolaborasi antar Stakeholder dalam Pengembangan Kawasan Minopolitan di Kabupaten Sidoarjo). http://repositor.unair.ac.id/67685. Diakses pada tanggal 25 September 2018.

Ansell. C \& Gash. A. 2008. Collaborative Governance in Theory and Practice. Journal of Public Administration Research and Theory, 1-29.

Hadji, Kuswan. Dkk. 2017. Potensi dan Pengembangan Wahana Obyek Wisata Alam sebagai Daya Tarik Wisata Edukasi Keluarga di Kabupaten Magelang.

http://journal.ummgl.ac.id/index.php/urecol/article/download/1014/751. Diakses pada tanggal 19 September 2018.

Junaidi, 2015. Collaborative Governance Dalam Upaya Menyelesaikan Krisis Listrik Di Kota Tanjungpinang. http://jurnal.umrah.ac.id/wpcontent/uploads/gravity_forms/1ec61c9cb232a03a96d0947c6478e525e/20 16/08/jurnal-1.pdf. Diakses pada tanggal 29 Agustus 2019.

Kurniawan, Fandy. 2013. Kemitraan Pengelolaan Sektor Pariwisata (Studi pada Tirta Wisata Kabupaten Jombang). http://administrasipublik.studentjournal.ub.ac.id/index.php/jap/article/vie w/10. Diakses pada tanggal 27 Agustus 2018.

Misna, Andi. 2015. Formulasi Kebijakan Alokasi Dana Desa di Desa Kandolo Kecamatan Teluk Pandan Kabupaten Kutai Timur. http://www.portal.fisip-unmul.ac.id/site/?p=2963. Diakses pada tanggal 19 September 2018.

Murdiastuti, Anastasia. 2014. Kebijakan Pengembangan Pariwisata Berbasis Democratic Governance. Surabaya : Pustaka Radja. Diakses pada tanggal 23 September 2018.

Sambodo, Giat Tri. 2016. Pelaksanaan Collaborative Governance di Desa Budaya Brosot, galur, Kulonprogo, DI. Yogyakarta. 
FisiPublik : Jurnal IImu Sosial dan Politik

https://journal.uwgm.ac.id/index.php/fisipublik

P-ISSN: 2528-2689; E-ISSN: 2540-9751

Vol 04 No 02 November 2019,

http://journal.umy.ac.id/index.php/GPP/article/download/2140/2068.

Diakses pada tanggal 23 September 2018.

Sedarmayanti. 2015. Membangun Kebudayaan dan Pariwisata. Bandung : Penerbit Mandar Maju. Diakses pada tanggal 19 September 2018

Sudarmo dan Tika Mutiarawati, 2017. Collaborative Governance dalam penanganan Rob di Kelurahan Bandengan Kota Pekalongan. Jurnal Wacana Publik. Vol 1 No 2. Diakses pada tanggal 19 September 2018

Yoeti, O. A. 2008. Ekonomi Pariwisata. Introduksi, Informasi, dan Implementasi. Jakarta : Kompas. Diakses pada tanggal 23 September 2018

Undang-Undang Republik Indonesia Nomor 12 tahun 2008 tentang Pemerintahan Daerah

Undang-undang Nomor 23 tahun 2014 tentang Pemerintah Daerah

Peraturan Pemerintah Republik Indonesia No 50 tahun 2011 tentang Rencana Induk Pembangunan Kepariwisataan Nasional tahun 2010-2025

Peraturan Pemerintah Republik Indonesia No 18 tahun 2016 tentang Perangkat Desa 